\title{
Strategic management consulting in Hungary
}

\author{
Roland Schmuck \\ University of Pécs, Faculty of Business and Economics, Pécs, Hungary
}

\begin{abstract}
Several Hungarian SMEs are facing problems using management methodologies. The goal of the research is to analyze the Hungarian management consulting market based on two previous Hungarian surveys. Strategic management consulting is one of the most important management consulting topics. The purpose of this research is to understand the Hungarian strategic management consulting market better. Two surveys are compared with each other and the size of the Hungarian strategic consulting market is calculated based on these secondary data. Trends and problems in the industry are also described briefly. The results of this research contribute to better understanding of the developments happening in this industry.
\end{abstract}

\section{Keywords}

strategy, management, consulting, Hungary

\section{Introduction}

Most of Hungarian businesses are small and medium enterprises which were founded after the change of the regime in Hungary in 1989. The problem is that many of these companies grew in the last decades solely by the professional knowledge and personal connections of their founder and owner lacking the appropriate knowledge of management sciences. There is an urgent need for these companies to develop their management skills and use up-to-date strategic management methodologies to be able to develop further and increase their competitiveness. The use of strategic management consulting can help these companies to achieve their goals.

The purpose of this paper is to describe the Hungarian strategic management consulting market. Several Eastern European countries are in a similar economic situation, where small and medium enterprises are facing similar problems as in Hungary. This research gives an opportunity to better understand one of these markets: the Hungarian market.

The object of the research is to analyze the Hungarian strategic management consulting industry after a brief introduction of strategic management consulting as a service. There is not much detailed information available on this market. The research estimates the market size and shows the market trends of the Hungarian strategic management consulting sector. The research questions are the following:

1. What is the market size of the Hungarian strategic management consulting market?

2. What are the main trends in the Hungarian strategic management consulting market?

The article shows up-to-date data by a comparison of previous surveys and gives an own estimation of the size of the Hungarian strategic management consulting market.

Tasks of the research is to describe strategic management and differentiate it from strategic planning. This literature review consists of publications in strategic management. The paper shows what strategic consultants are doing and which are the main problems they are facing. The main part of the research is to reanalyze previously published data. Two third-party researches are shown and analyzed according to strategic management consulting. 


\section{The importance of strategic management}

Traditional method of strategy development is strategic planning which is the planning of company goals under static or slowly changing corporate environmental conditions (Barakonyi, 1999). Strategy can be divided into functional strategies or geographical strategies (Bartek-Lesi et al., 2007). Strategic priorities are important issues (Chivu, 2019). There is a need for strategic planning to access or develop markets (AngeloskaDichovska \& Mirchevska, 2017). The external environment changes are happening so rapidly nowadays that the changes in the environment have to be taken into consideration as well. In modern, dynamic, environments, strategic management is becoming more vital for firms than ever before (Bao, 2015). This evolved strategic planning into strategic management (Barakonyi, 2000). Strategic management is an art and science of formulating, implementing and evaluating cross-functional decisions that enable an organization to achieve its objectives. Because of this, strategic management integrates management and other functional areas of the company (David \& David, 2015). Strategic managers have to lead, communicate, encourage and influence to influence the expected outcomes (Rosenzweig, 2013).

Knowledge economy is reshaping businesses (Hadad, 2018, Bratianu, Prelipcean, \& Bejinaru, 2020). A great strategy can be a good start for a business, but it does not mean that this strategy is easy to follow and the company will be competitive just by using appropriate planning techniques, such as the Interpretative Structural Modeling (Susilo, Ciptomulyono, Putra, Ahmadi, \& Suharyo, 2019). Implementing is a very important issue but unfortunately most companies struggle with implementation (Neilson, Martin, Powers, 2008). Strategic management emphasizes long-term performance over short-term. There is a need of sustainable investments strategy (Popescu, Andrei, Nica, \& Panait, 2019). Only 13 companies have survived so far from the original Forbes 100 companies listed in 1917. To be able to succeed in long-term companies have to adopt to new and changing market trends (Wheelen, Hunger, Hoffman, \& Bamford, 2017) and satisfy critical success factors (Jelača \& Boljević, 2016).

Most of the companies are unable to implement their strategies. The reasons can be the following:

- Awareness: 95\% of the typical workforce does not understand the strategy.
- Financial resources: $60 \%$ of organizations do not link budgets to strategy.

- Governance: $44 \%$ of board directors cannot identify the key drivers of value in the companies they govern.

- Executive agenda: $85 \%$ of executive teams spend less than one hour per month discussing strategy.

- Incentives: $70 \%$ of organizations do not link middle management incentives to strategy.

- People: $55 \%$ of human resources (HR) organizations either interpret strategy or deal only with operational priorities (Renaissance \& Business Intelligence, 1996).

A survey involving 354 company executives shows that the leaders of companies consider one of the most important business challenge is how to implement their strategy. Leaders noticed this issue and many of them started initiatives to better formalize and implement the company strategy (Provice, 2017). A vast majority, $70 \%$ of companies with formalized strategic implementation processes, have better performance than companies not using these management practices (Provice, 2017). An accurate perception of the environment is crucial for implementing strategies (Molina, del Pino, \& Rodríguez, 2004, Pham, Phan, Tučková, Vo, \& Nguyen, 2018). The key is to make sure companies can effectively execute the right things. As the proverb says: "The main thing is to keep the main thing the main thing." (Covey, Merrill, \& Merrill, 1994).

Strategic planners are those people in an organization who are specialized on ensuring the organization to develop and implement an appropriate strategy. Strategy is developed in consensus of the strategic planners and the management of the organization. After the strategic plan is ready it has to be widely communicated within the organization. (Arnold \& Bernstein, 2006). There is a need to plan and implement a strategic communication to achieve the company's mission and overall strategy (Mitrović, 2019). If the organization emphasizes the strategy consequently in its decisions the strategy will most probably be implemented. (Arnold \& Bernstein, 2006).

\section{The role of strategic management consulting}

The strategic orientation of the management of companies in accordance with the modern global trends is inevitable (Milićević, Backović, 
Sofronijević, 2015). The "product" of consultant companies is the intellectual property of their consultants which is actually the accumulation of special skills and knowledge. Consulting is a service where consultants stimulate their clients to make changes. The future success is important, but the previous knowledge of consultants may give some "guarantee" on good ideas and proposals. Consultants should be ready to handle unexpected situations in strong cooperation with the organization. Consultant is a helper hand for the organization (Biswas \& Twitchell, 2006).

Consultants who concern themselves with issues like basic goals or mission, business policy and strategy, planning, structuring and control of an organization are strategic or general management consultants. They are different than those consultants who consult in a specialized functional area like finance or marketing (Kubr, 2002). Organizations are facing potential hazardous events (Paunescu, Popescu, Blid, 2018), such as the current COVID-19 situation. Companies with deteriorating results, in crisis or near crisis may need the help of such consultants.
In these cases the top management may be out of ideas where the company is heading and what to do. In other cases the management may identify the goals well but they are unable to implement the strategies leading to them (Kubr, 2002). Furthermore, in a turbulent environment the strategic planning process is needed to be supplemented with a dynamic strategic issue management system (Perrott, 2011).

Strategic management consulting is part of management consulting, so the features of management consulting applies to this type of consulting as well:

- Management consulting should be done on base of a contract.

- Consultants are independent of the company which receives the consulting activity.

- Consultants should not decide on their ideas and proposals.

- Consultants should only cooperate in implementing their proposals if they are asked to do that (Hoványi 1997).

Table 1 Goal and functions of strategic planning

\begin{tabular}{|c|c|}
\hline Goal and function of strategic planning & Description \\
\hline Proposal & $\begin{array}{l}\text { Informing the top management of the proposed strategic steps } \\
\text { with the help of analysis. }\end{array}$ \\
\hline Determinate course line & $\begin{array}{l}\text { Facilitate competitive short-, middle-, or long-term strategies with } \\
\text { the help of company ideas and analysis. It can be implemented } \\
\text { through three methods: top-down, down-top or hybrid of the two. }\end{array}$ \\
\hline Motivational paradigm shift & $\begin{array}{l}\text { Raising provocative business ideas and motivating managers to } \\
\text { differ from ordinary strategies and tactics. }\end{array}$ \\
\hline Analyze strategic business information & Analyzing information to help the work of the top management. \\
\hline Encouragement and motivation & $\begin{array}{l}\text { Persuasion of the affected groups within the organization and } \\
\text { motivate them to use business ideas. }\end{array}$ \\
\hline Provide intellectual property to business decisions & $\begin{array}{l}\text { Creating of databases and make analysis to support } \\
\text { management decisions in mainly those cases which are } \\
\text { important by a strategic view (e.g. company mergers and } \\
\text { acquisitions). }\end{array}$ \\
\hline "Think tank" or inexhaustible storehouse of ideas & $\begin{array}{l}\text { Creating of analysis and definition of statements to solve } \\
\text { business problems. }\end{array}$ \\
\hline
\end{tabular}

Any consultant service includes changes in the organization - let it be strategic plan or business process reengineering (Maira, 2006). This causes that consultants need to use change management techniques. There is usually no guarantee that the proposals of the consultant will work. However, Biech suggests that consultants should offer $100 \%$ money-back guarantee for the work done (Biech, 2006).

Strategic consultants concentrate on the five main subjects of the strategic consulting process as shown in Figure 1.
Any consultant service includes changes in the organization - regardless of whether it is strategic plan or business process reengineering (Maira, 2006). Consultants need to apply change management methods, but even with proper usage of these methods there can be no guarantee that the proposals of the consultant will work. Biech suggests that consultants should offer $100 \%$ money-back guarantee for the work done (Biech, 2006). This is more risky for the consultant but reduces the risks of the customer. 
Strategic management consulting concentrates on five main subjects that is illustrated in Figure 1.

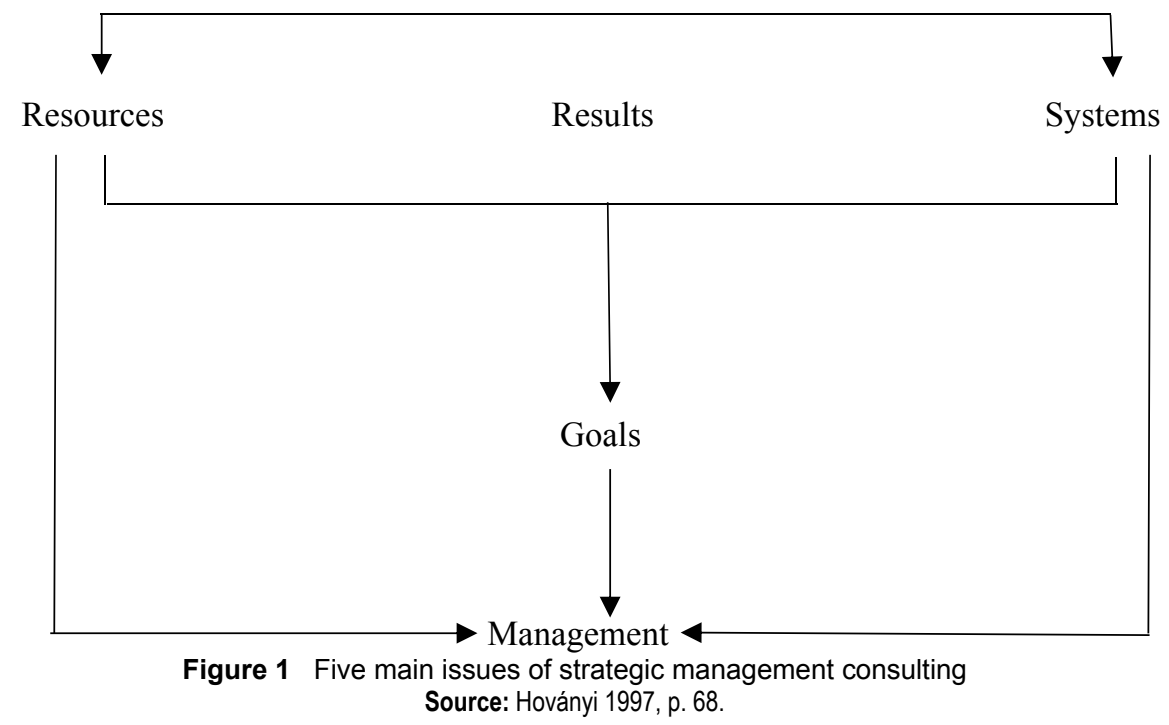

Ordinary company resources are capital, technology, human resources and natural resources. Using a modern view these resources can be extended by six further resources: (1) information, (2) innovation potential, (3) coordination, (4) intangible assets, (5) fit in the vertical value chain and (6) time (Hoványi, 1997).

Systems stand for the functional parts and their cooperation inside the company. Companies are built up of smaller subsystems which should be synchronized with each other.

Consultants should help to develop the company in measurable results. The quantified results can be considered the most important which may be included in the company balance sheet and income statement. Key Performance Indicators (KPIs) are monitoring the success and in modern companies they also proactively drive it (Schrage, 2019). Results are directly connected to the goals. Managers should have specified goals for the whole company and for the company subsystems as well. Goals may affect the environment of the company as well: some organizations have social goals to achieve next to their internal goals (Hoványi, 1997). Digital orientation undoubtedly became part of modern strategic management goals (Fosić, Trusić, \& Šebalj, 2017). The digital transformation needs proactive leadership (Kontić \& Vidicki, 2018).

Strategic consultants should help the company to develop competitive advantages. This can be based on company resources, systems, goals, results or leadership. The realized competitive advantage always depends on the features of the company and the environment, the strong and weak points of the competitors. Competitive advantage should be built in permanent (sub)systems. The developing costs of the skills causing competitive advantages should be low compared to the positive outcome of these advantage (Hoványi, 1997).

\section{The strategic management consulting market in Hungary}

Most of the information available is about the whole Hungarian consulting market. There is a lack of detailed information on the strategic management consulting market. To describe the state of the strategic management consulting in Hungary in this section, I compare two surveys (Poór 2014, 2015) and show the available information on the market size which makes it possible to estimate the size of the strategic management consulting market in Hungary.

The total market size of the management consulting market can only be estimated. An estimation based on the members of the Hungarian Association of the Management Consultants (called VTMSZ) is that the total consulting market is about 50.000.000.000 Hungarian Forints (which is about 160 million Euros calculated by the average 316.5 HUF/Euro rate in 2015). (MNB, 2015) From this value approximately 23.500.000.000 Hungarian Forints (about 74.2 million Euros) is the market of management consulting (Vicze, 2014). 
Most of the VTMSZ member companies are small, with less than 10 employees. VTMSZ member companies cope with minimum three consulting topics (Vicze, 2014). Consulting companies coping exclusively with strategic management problems are very uncommon in Hungary.

In the following part two surveys are shown with the goal to reanalyze their data and show trends over time. The survey of Szent István University and the Consulting Roundtable shows the occurrence of different types of business consulting. There were 150 questionnaires answered by Hungarian companies in this survey. Each company could give up to three answers regarding its activities. The most common business consulting activities are operation and organization $(56.67 \%)$, project management $(50 \%)$ and strategic management consulting (42\%) (Poór, 2014).

This survey indicates that the most common operations in Hungary after the financial crisis was to start new activities and the second most common activity was to redefine the strategy of the company (Poór, 2014). Participating companies in the survey were asked about which consultancy field is increasing or decreasing by their own estimations. The use of the consulting services show that strategic management and HR consulting activities declined mostly. This probably indicates that the market of these consulting services became saturated.

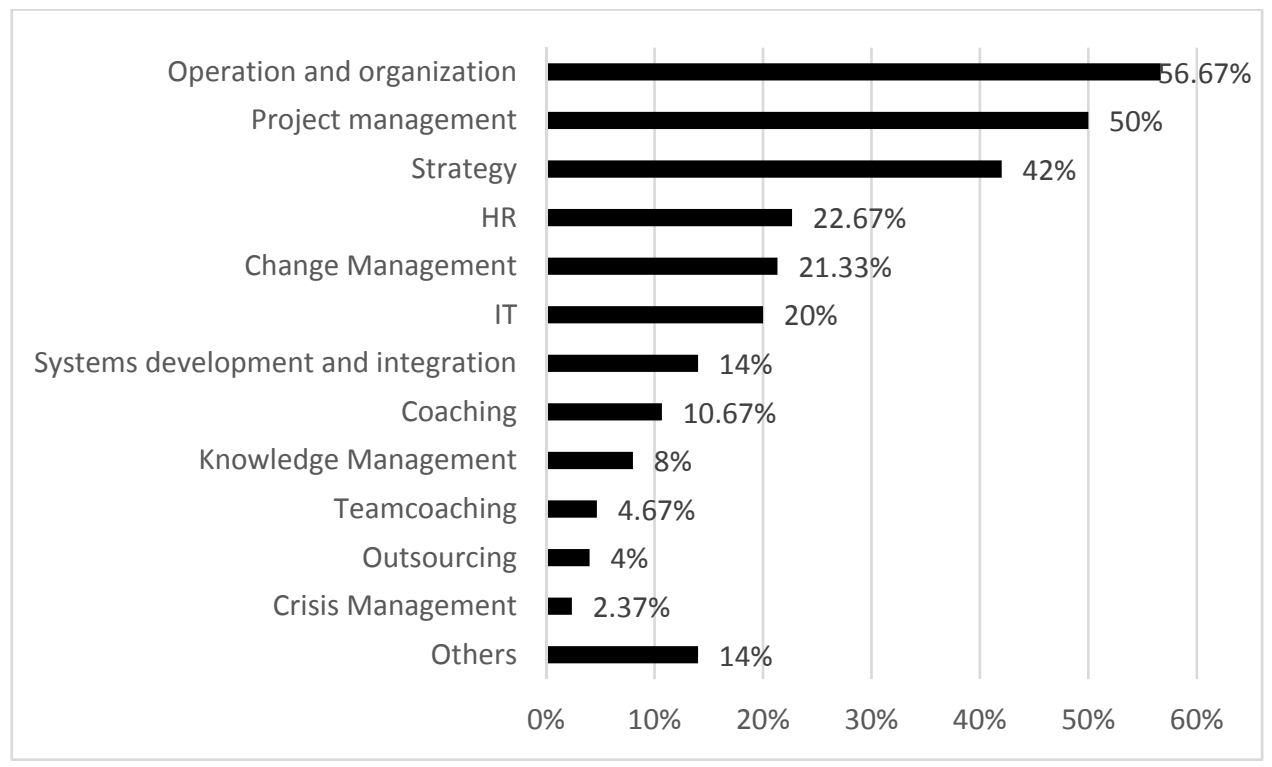

Figure 2 Most common business consulting activities in Hungary in 2014 Source: Poór 2014, p 10.

A similar survey was done in 2015. 130 companies participated in this survey. Hungarian companies could give up to three answers to the most common consulting activities used. The report of the research only gives relative numbers to each other which is not directly comparable to the 2014 numbers. In this survey, the most frequent consulting services in Hungary are operations $(20 \%)$, strategy $(15 \%)$ and project management $(15 \%)$. The order is similar to the survey of 2014 (Poór, 2015). 


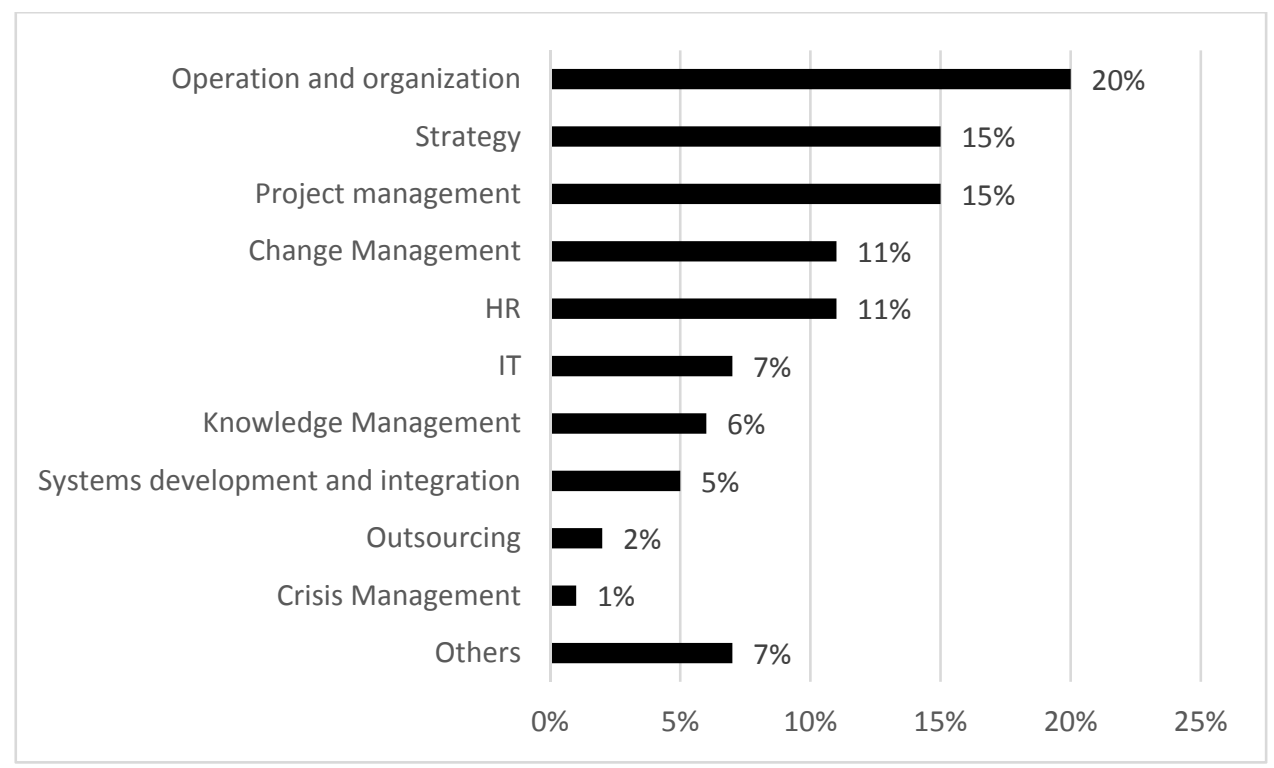

Figure 3 Most common business consulting activities in Hungary in 2015 Source: Poór 2015, p. 8.

Based on the survey, strategic consulting includes development of strategic planning, mergers, acquisitions, sales and marketing, so overall strategic management.

To answer the first research question we need to compare the 2014 and 2015 surveys. The surveys are not directly comparable, so I recalculated the 2014 survey results to relative values such as the data available from the 2015 survey. The results confirm the prediction of the 2014 survey: strategic management consulting is decreasing. It decreased about one percentage point from about $16 \%$ to $15 \%$. The leading consultancy topics, such as operations consulting and project consulting also decreased. HR, change management and knowledge management increased the most.

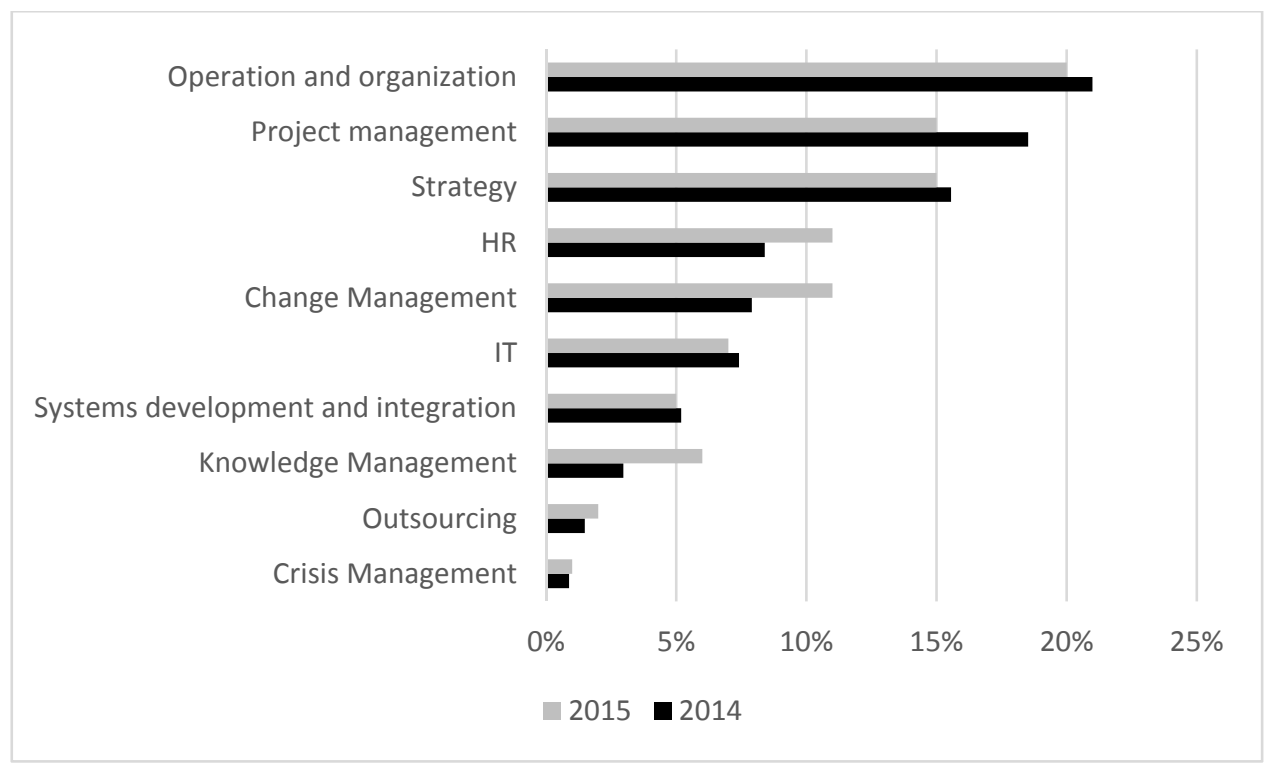

Figure 4 Most common business consulting activities in 2014-2015 in Hungary

Source: Own calculations based on Poór, 2014, 2015

Based on the Hungarian market size estimation by Vicze (2014), we can calculate the size of strategic management consulting market in Hungary. By calculating with $15 \%$ market share of 
the total market, the size of the strategic consulting market is 7.500.000.000 Hungarian Forints (which is about 23.7 million Euros). This gives answer to the second research question.

Strategic management consulting is not only very popular among business consulting but it is offered by many consulting companies in Hungary as well, including multinational companies. The best known traditional consulting companies in Hungary are Synergon, Ernst \& Young, KPMG, Deloitte (Mártonffy, 2009). There are small private companies and consulting entrepreneurs as well on the market. Gábor Kornai, the owner of AAM Consulting states that the hourly fees of consulting can be very different. Strategic management consulting has the highest hourly fees which can be around 300 Euros / hour (Mártonffy, 2009). Subsidiaries of the "big four" consultant companies can use even higher hourly fees. This allows the smaller-sized consulting companies and individual consultant entrepreneurs to gain market share. As there is no real guarantee on the proposals given by consultants, trust and previous experience is a major issue.

\section{Conclusion}

The research had a goal to estimate the size of the Hungarian strategic management consulting market and show which are the main trends in this consulting sector.

There is a wide variety of companies offering management consulting in Hungary: entrepreneurs, small companies and the "big four" consulting companies are present on the market.

Most Hungarian consulting companies are offering several different services, typically at least in three different topics. Strategic management consulting is a relevant topic in management consulting services as the surveys of 2014-2015 indicate. Trends show that the market share of strategic management consulting decreased lightly from $15 \%$ to $14 \%$ in one year to 2015 . This does not affect the fact that strategic management consulting still remains one of the leading consultant topics. In 2015 it is the second most used consulting service in Hungary after operation and organization consulting. The market size of strategic management consulting was estimated in this research. It is approximately 23.7 million Euros (equaling 7.500.000.000 HUF) in Hungary in 2015.

Researches show that strategic management consulting is one of the best paying consultant roles with the highest fees. The market share of big multinational consulting companies is high, but the high fees create market demand for smaller sized consulting companies and individual consultants offering cheaper prices. As there is no guarantee for the success of the consulting services trust and previous experience is an important decision factor for customers.

In the next few years we can expect changes in the focus of the business consulting in Hungary. While several topics are expected to remain important, such as the operation and organization consulting and the project management consulting, some other consulting fields are expected to gain market share. With the wider spread of digitalization among companies the role of IT consulting is expected to increase. The use of new IT-based business models highlights the importance of strategic management consulting. The COVID-19 pandemic can bring the strengthening of crisis management consulting. Local production may become preferable increasing the consulting needs in outsourcing or insourcing topics. However, the increasing demand in several consulting topics can be easily overwritten by a worldwide crisis situation. The whole business consulting market may face a crisis situation because of the COVID-19 pandemic, similar to the situation that happened after the financial crisis began in 2008.5M

\section{References}

Angeloska-Dichovska, M., \& Mirchevska, T. P. (2017). Challenges of the Company in the New Economy and Development of E-business Strategy. Strategic Management: International Journal of Strategic Management and Decision Systems in Strategic Management, 22 (2) 27-35.

Arnold, C., Bernstein, S. C. (2006). A stratégiatervezés mint belső tanácsadás. In Biswas,-Twitchell (editor): Menedzsment tanácsadás: Teljes körü útmutató az üzletághoz. Pécs: VHE.

Bartek-Lesi, M., Bartók, I., Czakó, E., Gáspár, J., Könczöl, E., \& Pecze, K. (2007). Vállalati stratégia. Budapest: Alinea Kiadó.

Barakonyi, K. (1999). Stratégiaalkotás I. Stratégiai tervezés. Budapest: Nemzeti Tankönyvkiadó

Barakonyi, K. (2000). Stratégiaalkotás II. Stratégiai menedzsment. Budapest: Nemzeti Tankönyvkiadó.

Bao, G. (2015). What theories are needed for strategic management? Nankai Business Review International, 6 (4) 433-454. https://doi.org/10.1108/NBRI-05-2015$\underline{0012}$

Biech, E. (2006). A tanácsadás világa. Az alapoktól kezdve... Pécs: VHE.

Biswas, S., Twitchell, D. (2006). Menedzsment tanácsadás: Teljes körü útmutató az üzletághoz. Pécs: VHE.

Bratianu, C., Prelipcean, G., \& Bejinaru, R. (2020). Exploring the latent variables which support SMEs to become learning organizations. Management \& 
Marketing. Challenges for the Knowledge Society, 15 , 2, 154-171. https://www.doi.org/10.2478/mmcks-2020-0010

Chivu, L. (2019. Local entrepreneurship and social services in Romania. Territorial analysis. European Research on Management and Business Economics, 25, 2, 79-86. https://doi.org/10.1016/j.iedeen.2019.04.001

Covey, S. R., Merrill, A. R., \& Merrill, R. R. (1994). First Things First. New York: Fireside.

David, F. R., \& David F. R. (2015). Strategic Management. A Competitive Advantage Approach, Concepts \& Cases. Fifteenth Edition. USA: Pearson Education.

Fosić, I., Trusić, A., \& Šebalj, D. (2017). Digital Organizational Strategy - Ticket for Competitiveness on the International Market. Strategic Management: International Journal of Strategic Management and Decision Systems in Strategic Management, 22 (3) 310.

Hadad, S. (2018). The geographic distribution of Knowledge Economy (KE) within the European Union (EU). Management \& Marketing. Challenges for the Knowledge Society, 13, 3, 1089-1107. https://www.doi.org/mmcks-2018-0025

Hoványi, G. (1997). Menedzsment tanácsadás. Pécs: Janus Pannonius Tudományegyetem Közgazdaságtudományi Kar.

Jelača, M. S., Boljević, A. (2016). Critical Success Factors and Negative Effects of Development - The Boeing 787 Dreamliner. Strategic Management: International Journal of Strategic Management and Decision Systems in Strategic Management, 21 (1) 30-39.

Kontić, L., Vidicki, Đ. (2018). Strategy for Digital Organization: Testing a Measurement Tool for Digital Transformation. Strategic Management: International Journal of Strategic Management and Decision Systems in Strategic Management, 23 (1) 29-35. https://doi.org/10.5937/StraMan1801029K

Kubr, M. (2002). Management Consulting: a Guide to the Profession. Forth Edition. Geneva: International Labour Office.

Maira, A. (2006). Tanácsadás a változásmenedzsment területén. In Biswas-Twitchell: Menedzsment tanácsadás: Teljes körü útmutató az üzletághoz. Pécs: VHE.

Mártonffy, A. (2009). A tanácsadó és a svindler. ITBusiness. Retrieved March 7, 2020, from http://www.itbusiness.hu/Fooldal/main_flash_banner/A_ tanacsado_es_a_svindler.html

Milićević, V., Backović, N., Sofronijević, A. (2015). Strategic Orientation of European Management in the Conditions of Globalisation. Strategic Management: International Journal of Strategic Management and Decision Systems in Strategic Management, 20 (2), 49-57.

Mitrović, M. (2019). Strategic communication concept implemented through the corporate political activities suggested strategy modeling. Strategic Management: International Journal of Strategic Management and Decision Systems in Strategic Management, 24 (4), 1320. http://doi.org/10.5937/StraMan1904013M

MNB (2015). MNB Középárfolyam Figyelö. http://www.mnbkozeparfolyam.hu/arfolyam-2015.html, accessed 7th March 2020

Molina, M. A., del Pino, I. B., \& Rodríguez, A. C. (2004). Industry, Management Capabilities and Firms' Competitiveness: An Empirical Contribution. Managerial and Decision Economics, 25: 265-281. https://doi.org/10.1002/mde.1148

Neilson, G. L., Martin, K. L., Powers, E. (2008). The Secrets to Successful Strategy Execution. Harvard Business Review: HBR's Must Reads on Strategy.

Paunescu, C., Popescu, M. C., Blid, L. (2018). Business impact analysis for business continuity: Evidence from Romanian enterprises on critical functions.

Management \& Marketing - Challenges for the Knowledge Society, 13 (3), 1035-1050. https://doi.org/10.2478/mmcks-2018-0021

Perrott, B. E. (2011). Strategic issue management as change catalyst. Strategy \& Leadership, 39 (5) 20-29. https://doi.org/10.1108/10878571111161499

Pham, N.T., Phan, Q.P.T., Tučková, Z., Vo, N. \& Nguyen, L.H.L. (2018). Enhancing the organizational citizenship behavior for the environment: the roles of green training and organizational culture. Management \& Marketing. Challenges for the Knowledge Society, 13, 4, 11741189.

https://www.doi.org/10.2478/mmcks-2018-0030

Poór J. (2014). Menedzsment tanácsadás helyzete Magyarországon. Menedzsment és HR Kutató Központ, Szent István Egyetem, GTK TTI.

Poór, J. (2015). Menedzsment tanácsadás módszereinek változása Magyarországon. Menedzsment és HR Kutató Központ, Szent István Egyetem, GTK TTI.

Popescu, G. H., Andrei, J. V., Nica, E., Mieilă, M., \& Panait, M. (2019). Analysis on the impact of investments, energy use and domestic material consumption in changing the Romanian economic paradigm.

Technological and Economic Development of Economy, 25 (1), 59-81.

https://doi.org/10.3846/tede.2019.7454

Provice (2017). Stratégia végrehajtási képességfejlesztés. Retrieved March 13, 2017, from

http://www.provice.hu/Strategia_Vegrehajtasi_Kepesse gfejlesztes

Renaissance, CFO \& Business Intelligence (1996). Translating Strategy into Action. Joint study by Renaissance Solutions Inc., CFO Magazine and Business Intelligence magazine, and Business Intelligence

Rosenzweig, P. (2013). What Makes Strategic Decisions Different. Harvard Business Review, 2013 November 89-93.

Schrage, M. (2019). Smart Strategies Require Smarter KPIs. MITSloan Management Review, September 16, 2019.

Susilo, A. K., Ciptomulyono, U., Putra, I. N., Ahmadi, \& Suharyo, O. S. (2019). Navy Ability Development Strategy using SWOT Analysis-Interpretative Structural Modeling (ISM). Strategic Management: International Journal of Strategic Management and Decision Systems in Strategic Management, 24 (1), 30-40. https://doi.org/10.5937/StraMan1901030S

Vicze, G. (2014). Versenyképességi tényezők és kitörési lehetőségek a magyar szolgáltató szektorban - a vezetési tanácsadás esete. $\mathrm{PhD}$ dissertation. Veszprém: Pannon Egyetem, Gazdálkodás- és Szervezéstudományok Doktori Iskola.

Wheelen, T. L, Hunger, J. D., Hoffman, A. N., \& Bamford C. E. (2017). Concepts in Strategic Management and Business Policies. Globalization, Innovation and Sustainability. Fifteenth Edition. USA: Pearson Education. 


\section{$\triangle$ Correspondence}

\section{Dr. Roland Schmuck}

University of Pécs, Faculty of Business and Economics Rákóczi út 80, H-7622 Pécs, Hungary

E-mail: schmuck.roland@ktk.pte.hu 